\title{
Maxillary sinusitis with unusual image on cone-beam computed tomography
}

\author{
Sinusite maxilar com imagem incomum na tomografia computadorizada de feixe cônico \\ Sinusitis maxilar con imagen inusual en la tomografía computarizada de haz cónico
}

Received: 04/06/2021 | Reviewed: 04/13/2021 | Accept: 07/22/2021 | Published: 07/30/2021

\author{
Angie Patricia Castro-Merán \\ ORCID: https://orcid.org/0000-0001-5817-1636 \\ São Paulo State University, Brazil \\ E-mail: castroap@usp.br \\ Letícia Dragonetti Girotti \\ ORCID: https://orcid.org/0000-0001-6239-6096 \\ São Paulo State University, Brazil \\ E-mail: legirotti@gmail.com \\ Géssyca Guimarães \\ ORCID: https://orcid.org/0000-0003-4207-3577 \\ São Paulo State University, Brazil \\ E-mail: gessycaguimaraes@usp.br \\ Jéssica Segantin \\ ORCID: https://orcid.org/0000-0002-5766-0937 \\ São Paulo State University, Brazil \\ E-mail: jessicafsegantin@gmail.com \\ Eduardo Sanches Gonçales \\ ORCID: https://orcid.org/0000-0002-6682-7006 \\ São Paulo State University, Brazil \\ E-mail: eduardogoncales@usp.br \\ Osny Ferreira Júnior \\ ORCID: https://orcid.org/0000-0002-5813-3127 \\ São Paulo State University, Brazil \\ E-mail: osnyfjr@fob.usp.br
}

\begin{abstract}
The maxillary sinuses are the largest of the paranasal sinuses. They consist of pneumatized bilateral cavities, lined by respiratory mucosa, identical to the nasal mucosa, consisting of pseudostratified epithelium, with hair cells and goblet cells, producing mucus. Radiographically, the maxillary sinus is seen as a radiolucent area, ovoid or rounded, with a well-defined contour, delimited by a continuous radiopaque line or with small interruptions and radiolucency similar to that of the orbit. When a change in the maxillary sinus is suspected, images of the sinus are usually found, the presence of septa, thickening of the mucosa, or polyps. Sinusitis is the main pathology of the maxillary sinus, being of multifactorial etiology, and may be due to anatomical, environmental factors or viral, bacterial, or fungal infections. The diagnosis of sinusitis is clinical, but it can be confirmed by imaging exams such as panoramic radiography or cone beam computed tomography (CBCT). Case Presentation: In this case of a 21-year-old patient treated by the FOB-USP Surgery team, due to the proximity of the third molar to the maxillary sinus, a cone-beam scan was performed in which bubbles were noted on the surface of the maxillary sinus content. The image is compatible with sinusitis however, the presence of bubbles is a very unusual image in this type of alteration of the maxillary sinus. Conclusions: CT images with fluid levels and bubbles on their surface, although uncommon in dental practice, are characteristic of acute sinusitis and the dentist must have this knowledge for the correct diagnosis of maxillary sinusitis.
\end{abstract}

Keywords: Maxillary Sinus; Sinusitis; Cone Beam Computed Tomography.

\section{Resumo}

Os seios maxilares são os maiores dos seios paranasais. Consistem em cavidades bilaterais pneumatizadas, revestidas por mucosa respiratória, idêntica à mucosa nasal, sendo constituídas por epitélio pseudoestratificado, com células ciliadas e caliciformes, produtoras de muco. Radiograficamente, o seio maxilar é visto como uma área radiolúcida, de forma ovoide ou arredondada, com contorno bem definido, delimitado por linha radiopaca contínua ou com pequenas interrupções e radiolucidez semelhante à da órbita. Quando se tem suspeita de alteração no seio maxilar, geralmente são encontrados, nas imagens, velamento do seio, presença de septos, espessamento da mucosa ou pólipos. A sinusite é principal patologia do seio maxilar, sendo de etiologia multifatorial, podendo se dever a fatores anatômicos, ambientais ou infecções virais, bacterianas ou fúngicas. O diagnóstico da sinusite é clínico, porém pode ser confirmado por exames de imagem como radiografia panorâmica ou tomografia computadorizada de feixe cônico (TCFC). Presentamos um Caso Clinico caso de um paciente de 21 anos, atendido pela equipe de Cirurgia da FOB-USP, devido a proximidade do terceiro molar com o seio maxilar foi realizada 
tomografia de feixe cônico na qual foram notadas bolhas na superfície do conteúdo do seio maxilar. A imagem é compatível com sinusite, entretanto a presença de bolhas é uma imagem bastante inusitada nesse tipo de alteração do seio maxilar.

Palavras-chave: Seio Maxilar; Sinusite; Tomografia Computadorizada de Feixe Cônico.

\section{Resumen}

Los senos maxilares son los más grandes de los senos paranasales. Consisten en cavidades bilaterales neumatizadas, revestidas por mucosa respiratoria, idéntica a la mucosa nasal, estando constituidas por epitelio pseudoestratificado, con células ciliadas y caliciformes, productoras de moco. Radiográficamente, el seno maxilar se ve como un área radiolúcida, ovoide o redondeada, de contorno bien definido, delimitado por una línea radiopaca continua o con pequeñas interrupciones y radiolucidez similar a la de la órbita. Cuando se sospecha un cambio en el seno maxilar, suelen encontrarse imágenes del seno en las imágenes, presencia de septos, engrosamiento de la mucosa o pólipos. La sinusitis es la principal patología del seno maxilar, siendo de etiología multifactorial, que puede deberse a factores anatómicos, ambientales o infecciones virales, bacterianas o fúngicas. El diagnóstico de sinusitis es clínico, pero puede confirmarse mediante pruebas de imagen como la radiografía panorámica o la tomografía computarizada de haz cónico (CBCT). El objetivo de este estudio es presentar un Caso Clínico de un paciente de 21 años tratado por el equipo de Cirugía FOB-USP, debido a la proximidad del tercer molar al seno maxilar, se le realizó un escaneo de haz cónico en el que se notaron burbujas en la superficie del maxilar. contenido de los senos nasales. La imagen es compatible con sinusitis, sin embargo, la presencia de burbujas es una imagen muy inusual en este tipo de alteración del seno maxilar.

Palabras clave: Seno maxilar; Sinusitis; Tomografía Computarizada de Haz Cónico.

\section{Introduction}

The maxillary sinuses are cavities or compartments located within the bones of the maxilla, the largest being the paranasal sinuses (Zachary et al., 2020). They are covered by a ciliated pseudostratified columnar epithelium, of the respiratory type originating from nasal mucosa invaginations in the third month of intrauterine life (Fahrioglu et al., 2020). The growth of the maxillary sinuses occurs through pneumatization, between 12 and 14 years of age reaches the level of the nasal fossa floor, an age that coincides with the eruption of the upper second permanent molars (Lima et al., 2017)

Goblet cells, mucous and seromucous glands are responsible for the production of mucus, which is moved by the cilia towards the ostium. This transport represents a barrier to microorganisms and inhaled particles. For the correct functioning of the paranasal sinuses, patency of the Ostia, ciliary function, and quality of nasal secretions are necessary. (London \& Ramanathan, 2018)

In some cases, changes in the sinus mucosa (edema) can lead to narrowing and obstruction of the sinus ostium, preventing the normal flow of secretions and consequent infection. (Velayudhan et al., 2017).

Inflammation of the mucous lining of the paranasal sinuses is known as sinusitis. This condition can include edema of the mucosa, dysfunction of the mucosal cilia, and obstruction of the sinus Ostia. As the sinus mucosa is contiguous to the nasal mucosa, both portions can sometimes be affected, which is called rhinosinusitis. (Wyler \& Mallon, 2019)

Most sinus infections have a viral etiology, bacterial sinusitis represents only $2 \%$ to $10 \%$ of cases. (Galdo et al., 2012) Other etiologies have also been reported, ranging from allergic and non-allergic rhinitis, fungal infection, chemical irritation, and predisposition to obstruction of the individual due to anatomical variants. (Ah-See, 2007)

Computed tomography is the exam of choice to assess sinusitis complications, as it allows for more accurate observation of details related to sinus pathology, bone and adjacent anatomical structures. Among the findings in the acute sinusitis images, we can find a level of fluid or foamy secretions (with air dispersion). The thickening of the polypoid mucosa can occur in both acute and chronic sinusitis. Sclerosis and bone thickening are characteristics of chronic sinusitis (Velayudhan et al., 2017).

Acute bacterial sinusitis is characterized by purulent nasal discharge accompanied by facial pressure or pain. Treatment consists of antibiotic therapy, the use of NSAIDs, as well as mucolytics and decongestants (Feldt et al., 2013).

The study by (Brook, 2011) evaluated the microbiology of acute and chronic sinusitis in smoking and non-smoking patients. As for acute sinusitis, $64 \%$ of the patients were smokers and 36\% were non-smokers. The predominant anaerobic 
bacteria were Peptostreptococcus spp, Fusobacterium spp, and gram-negative bacilli (Prevotella, Porphyromonas spp, Bacteroides spp). As for chronic sinusitis, 39\% were smokers and $61 \%$ were non-smokers. The predominant anaerobic bacteria in this group were Peptostreptococcus spp, Fusobacterium spp, and gram-negative (Prevotella spp, Porphyromonas asaccharolytica, and Bacteroides fragilis).

The presence of anaerobic bacteria is usually related to chronic sinusitis or odontogenic sinusitis (Brook, 2006). However, the microbiological analysis of a series of cases of acute sinusitis showed that more than a third of all cases had anaerobic bacteria, and no history of chronic or odontogenic sinusitis was found in any of the cases. The authors suggested the use of broad-spectrum antibiotics with coverage for Streptococcus species, Staphylococcus species, and anaerobic bacteria for cases of acute sinusitis. (Mulvey et 1., 2018)

Computed tomography in acute rhinosinusitis demonstrates partial or complete opacification, due to the presence of fluid in the paranasal sinuses, indicating purulence. This finding contrasts with chronic rhinosinusitis, which may show thickening of the mucosa, in addition, to complete opacification (Kolln \& Senior, 2008; Thaller \& Kennedy, 2008; Peter \& Hugh, 2011; Feldt et al., 2013; Haaga \& Boll, 2016; Newadkar, 2017; Jana \& Bhalla, 2018)

A fluid level is found only in $25-50 \%$ of patients with acute sinusitis (Peter et al., 2011). On the other hand, nonspecific imaging findings can be seen in $40 \%$ of asymptomatic patients (Kamalian et al., 2019). Thus, imaging findings should be interpreted with clinical and/or endoscopic findings. Acute sinonasal secretions are predominantly water and mucoid in nature.

Paranasal sinus abnormality has been reported to be present in up to $42.5 \%$ of asymptomatic patients referred for computed tomography for other reasons, for example, migraine (Havas et al., 1988).

\section{Methodology}

This is a case report, presenting a tomographic finding in the evaluation of third molars. Finding a radiopaque image inside the maxillary sinus, indicating acute sinusitis, but without symptoms. All patient data were kept confidential.

\section{Case Presentation}

A 21-year-old male patient presented for a consultation with an indication for extraction of third molars. Computed tomography was requested because of the proximity of the third molar with the maxillary sinus. On tomographic examination, an image compatible with sinusitis was observed, although the patient did not complain of symptoms related to sinusitis (Figure 1). In the tomographic sections, septum and liquid content were found causing the sinus to be veiled on the left side (Figure 2). By varying the tomographic sections, hypodense, bubble-shaped areas were observed on the surface of the sinus fluid (Figures 3 and 4). The conduct consisted of referring the patient to the otorhinolaryngologist, who indicated antibiotic therapy with clindamycin for 10 days. 
Research, Society and Development, v. 10, n. 9, e45010914698, 2021

(CC BY 4.0) | ISSN 2525-3409 | DOI: http://dx.doi.org/10.33448/rsd-v10i9.14698

Figure 1. Radiographic image showing sinusitis in the left maxillary sinus.

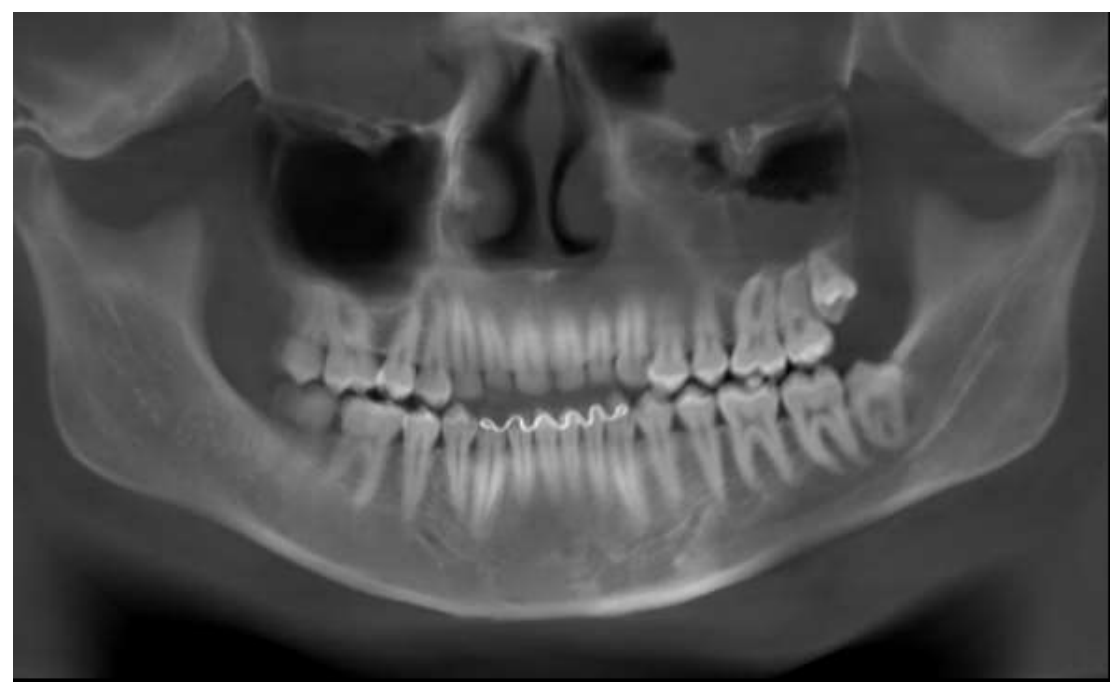

Source: Authors.

Figure 2. Veiling of the left maxillary sinus.
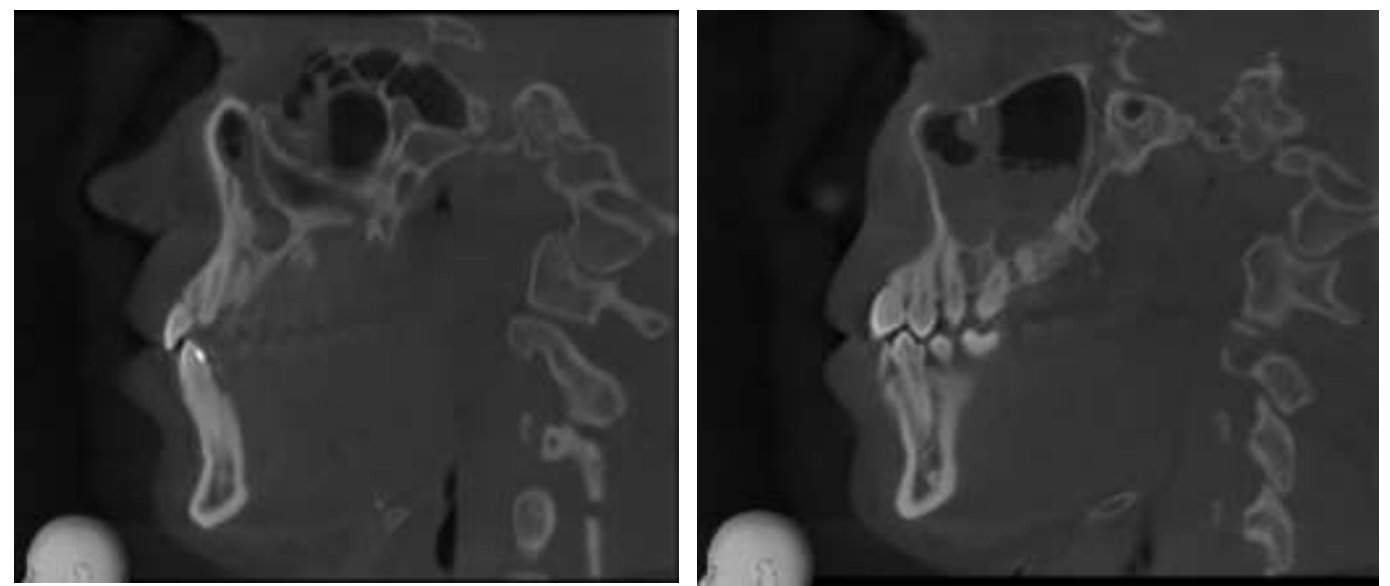

Source: Authors.

In Figures 1 and 2, we observe the veiling of the paranasal sinus, indicating sinusitis. The terms veiling or sinus opacification were used to refer to the filling of the sinus lumen with a hypoattenuating material, with an average density similar to that of the soft tissues. 
Research, Society and Development, v. 10, n. 9, e45010914698, 2021

(CC BY 4.0) | ISSN 2525-3409 | DOI: http://dx.doi.org/10.33448/rsd-v10i9.14698

Figure 3. Bubbles on the surface of the sinus fluid (a).
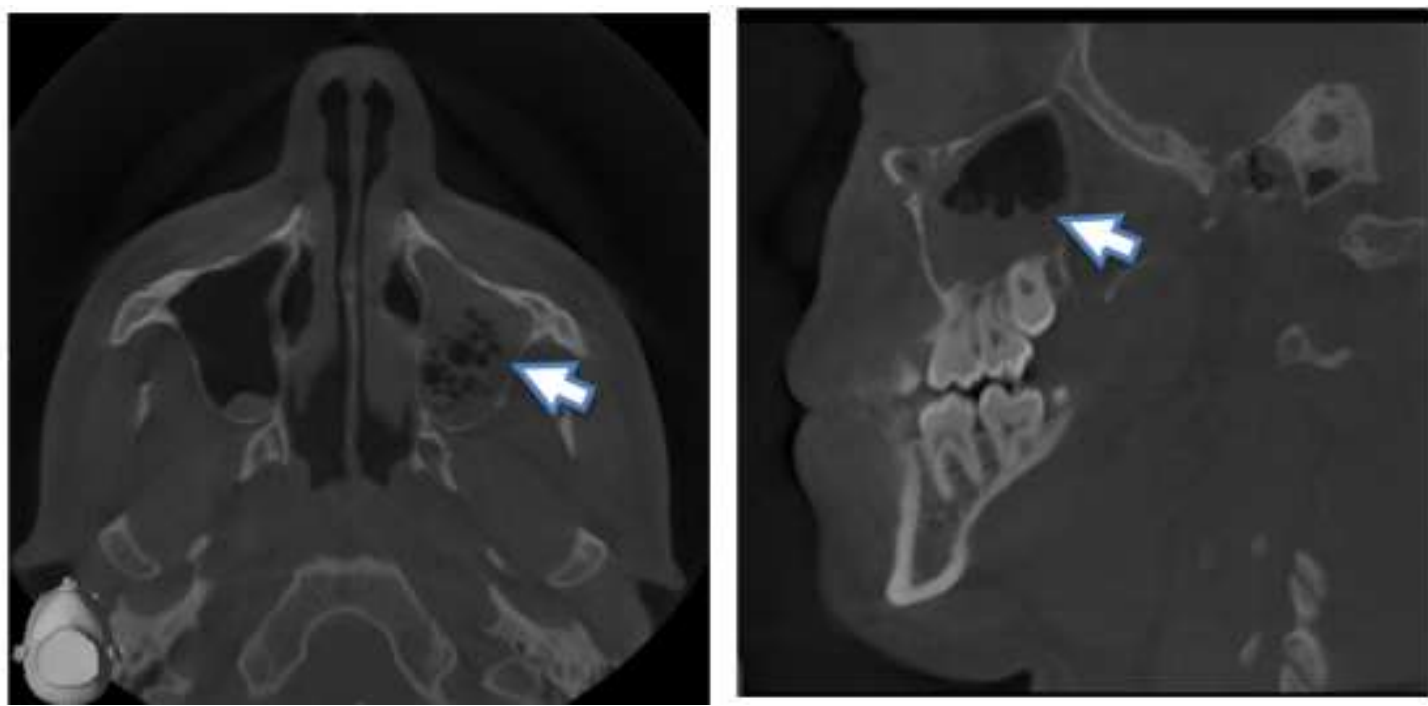

Source: Authors.

Figure 4. Bubbles on the surface of the sinus fluid (b).
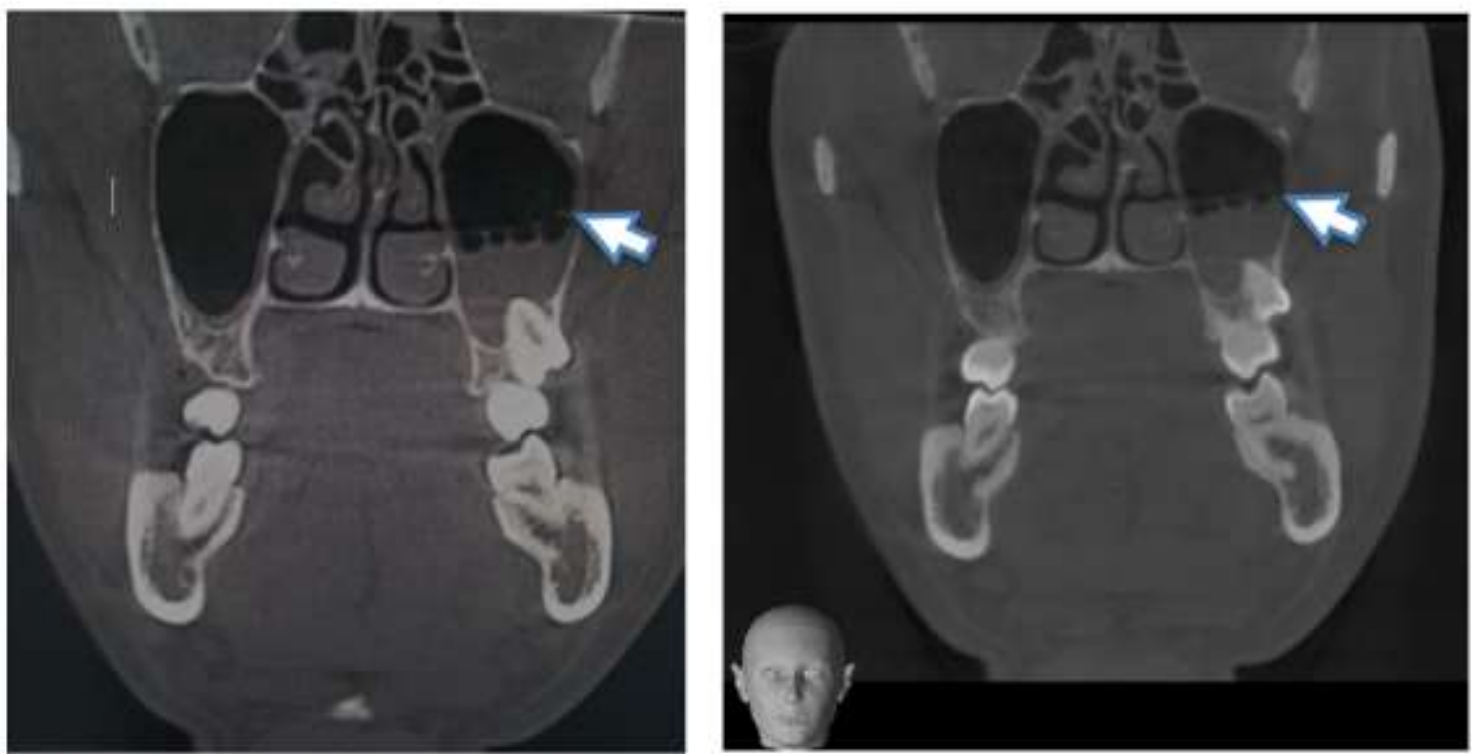

Source: Authors

In acute sinusitis, it commonly to find at the computed tomography, an accumulation of secretion forming an air-fluid level (bubbles) in the cavities and mucosal thickening as we can see in Figures 3 and 4.

Sinusitis can be diagnosed by the patient's clinical signs and symptoms or as a finding in the assessment of another condition such as migraine, and can present in asymptomatic patients (Snow et al., 2009) Likewise, our patient did not have any history or symptoms sinusitis and the diagnosis was obtained by assessing the proximity of the third molars to the maxillary sinuses for future tooth extraction.

On tomographic examination of the case, unusual images were found in a dental evaluation. The images had sinusitis compatibility with the appearance of "air bubbles" in the fluid within the maxillary sinus. These findings coincide with several studies that demonstrate the presence of air bubbles in the fluid of the maxillary sinus (Gwaltney et al, 2000; Thaller \& 
Kennedy, 2008; Peter \& Hugh, 2011; Feldt et al., 2013; Joshi, 2015; Haaga \& Boll, 2016; Newadkar, 2017; Jana \& Bhalla, 2018).

Because of the patient's absence of symptoms, the hypothesis that he sneezed prior to the computed tomography scan, leading to fluid movement in the paranasal sinuses and the formation of bubbles, was considered, as described by Gwaltney et al., (2000).

\section{Conclusion}

Tomographic images with fluid level and bubbles on its surface are radiographic features in the diagnosis of acute sinusitis. In dental practice, however, they are uncommon, being a clinical finding in the diagnosis of other pathologies. For this reason, the dental surgeon needs to have this knowledge for the diagnosis of maxillary sinusitis and correct referral.

We suggest carrying out future studies comparing the various tomographic and radiographic imaging instruments, in order to identify possible divergences in the analyzed images that could compromise the correct diagnosis.

\section{References}

Ah-See, K. W., \& Evans, A. S. (2007). Sinusitis and its management. Br Med J (Clinical research ed.), 334(7589), 358-361. https://doi.org/10.1136/bmj.39092.679722.BE

Anselmo-Lima, W. T., Sakano, E., Tamashiro, E., Nunes, A. A. A., Fernandes, A. M., Pereira, E. A., \& Pignatari, S. S. N. (2015). Rhinosinusitis: evidence and experience. A summary. Brazilian Journal of Otorhinolaryngology, 81(1), 8-18. https://doi:10.1016/j.bjorl.2014.11.005

Brook, I. (2006). The role of anaerobic bacteria in sinusitis. Anaerobe, 12(1), 5-12. https://doi:10.1016/j.anaerobe.2005.08.002

Brook, I., \& Hausfeld, J. N. (2011). Microbiology of Acute and Chronic Maxillary Sinusitis in Smokers and Nonsmokers. Annals of Otology, Rhinology \& Laryngology, 120(11), 707-712. doi:10.1177/000348941112001103

Feldt, B., Dion, G. R., Weitzel, E. K., \& McMains, K. C. (2013). Acute Sinusitis. Southern Medical Journal, 106(10), 577-581. https://doi 10.1097/SMJ.0000000000000002

Galdo J. A., Bridges M. T., Morris A. (2012). AN overview of the treatment and management of rhinosinusitis. US Pharmacist, 37(7): 27-30.

Gwaltney, J. M., Hendley, J. O., Phillips, C. D., Bass, C. R., Mygind, N., \& Winther, B. (2000). Nose Blowing Propels Nasal Fluid into the Paranasal Sinuses. Clinical Infectious Diseases, 30(2), 387-391. https://doi:10.1086/313661

Haaga J. C. R. \& Boll D. (2016). Computed Tomography \& Magnetic Resonance Imaging Of The Whole Body E-Book. Ed. Elsevier Health Sciences, Chapter 26, Pag. 689. ISBN-13: 978-0323113281

Havas, T. E., Motbey, J. A., \& Gullane, P. J. (1988). Prevalence of Incidental Abnormalities on Computed Tomographic Scans of the Paranasal Sinuses. Archives of Otolaryngology - Head and Neck Surgery, 114(8), 856-859. https://doi:10.1001/archotol.1988.01860200040012

Jana M., \& Bhalla A. S. (2018). Clinico Radiological Series: Sinonasal Imaging, Ed. Jp Medical Ltd (1 ${ }^{\circ}$ Edição) Chapter 4, pag. 54.

Joshi V. (2015) Imaging of Paranasal Sinuses, An Issue of Neuroimaging Clinics, V. 25-4, 1st Edition. eBook ISBN: 9780323413435

Kamalian, S., Avery, L., Lev, M., Schaefer, P., Curtin, H., \& Kamalian, S. (2019). Nontraumatic Head and Neck Emergencies. RadioGraphics. 39 (6): 18081823. https://doi.org/10.1148/rg.2019190159

Kia'I, N., \& Bajaj, T. (2019) Histology, Respiratory Epithelium. In: StatPearls. StatPearls Publishing, Treasure Island (FL).

Kölln, K. A., \& Senior, B. A. (2008). Diagnosis and Management of Acute Rhinosinusitis. Rhinosinusitis: A Guide for Diagnosis and Management, 1-11. https://doi.org/10.1007/978-0-387-73062-2_3.

Lima, C.O. et al. (2017) Sinusite odontogênica: uma revisão de literatura. Rev. Bras. Odontol. [online], vol.74, n.1, pp. 40-44.

London, N. R., \& Ramanathan, M. (2018). Sinuses and Common Rhinologic Conditions. Medical Clinics of North America. https:// doi:10.1016/j.mcna.2018.06.003.

Low, D. E., Desrosiers, M., McSherry, J., et al. (1997) A practical guide for the diagnosis and treatment of acute sinusitis. CMAJ; 156(suppl 6):S1-S14. PMID: 9347786

Mulvey, C. L., Kiell, E. P., Rizzi, M. D., \& Buzi, A. (2018). The Microbiology of Complicated Acute Sinusitis among Pediatric Patients: A Case Series. Otolaryngology-Head and Neck Surgery, 019459981881510. https://doi:10.1177/0194599818815109 
Research, Society and Development, v. 10, n. 9, e45010914698, 2021

(CC BY 4.0) | ISSN 2525-3409 | DOI: http://dx.doi.org/10.33448/rsd-v10i9.14698

Newadkar, U. R. (2017). Sinus radiography for sinusitis: "Why" and if considering it then "how"?. J Curr Res Sci Med, 3:9-15. https://doi: 10.4103/jcrsm.jcrsm_13_17

Peter, M. S., \& Hugh, D. (2011) Curtin. Head and Neck Imaging. p. 173. eBook ISBN: 9780323248938

Fahrioglu, S. L., VanKampen, N., \& Andaloro C. (2020). Anatomy, Head and Neck, Sinus Function and Development. Treasure Island (FL): StatPearls Publishing; Jan-. Disponível em: https://www.ncbi.nlm.nih.gov/books/NBK532926/

Snow, J. B., Wackym, P. A., \& Ballenger, J. J. (2009). Ballenger's otorhinolaryngology: Head and neck surgery. Shelton, Conn: People's Medical Pub. House/B C Decker. Chapter 46: Acute Rhinosinusitis and Its Complications.

Souza, C. F., Loures, A. O; Lopes, D. G. F., \& Devito, K. L. (2019). Analysis of maxillary sinus septa by cone-beam computed tomography. Rev. odontol. UNESP (48) e20190034. https://doi.org/10.1590/1807-2577.03419.

Thaller, E.R., \& Kennedy, D.W. (2008) Rhinosinusitis: a guide for diagnosis and management. Ed Springer, e-Book. Chapter: Diagnosis and Management of Acute Rhinosinusitis, pg. 34-38. ISBN 978-0-387-73062-2.

Velayudhan, V., Chaudhry, Z. A., Smoker, W. R. K., Shinder, R., \& Reede, D. L. (2017). Imaging of Intracranial and Orbital Complications of Sinusitis and Atypical Sinus Infection: What the Radiologist Needs to Know. Current Problems in Diagnostic Radiology, 46(6), 441-451. https://doi: 10.1067/j.cpradiol.2017.01.006

Wyler, B., \& Mallon, W. K. (2019). Sinusitis Update. Emergency Medicine Clinics of North America, 37(1), 41-54. https://doi:10.1016/j.emc.2018.09.007

Zachary, J. C., Katrina, M., \& Arthur, B. D. (2020). Anatomy, Head and Neck, Nose Paranasal Sinuses. Treasure Island (FL): StatPearls Publishing; Jan-. Disponível em: https://www.ncbi.nlm.nih.gov/books/NBK499826/ 